\title{
グラウトしたセラミックスメーソンリーの中性化 CARBONATION OF GROUTED CERAMICS MASONRY
}

\author{
馬場 明生*，守 明子** \\ Akio BABA and Akiko MORI
}

\begin{abstract}
Carbonation processes of cementitious concrete through burnt clay ceramic face materials were examined experimentally, and a predictive equation is proposed for evaluating the controlling effects on carbonation in this paper. Four levels in compressive strength of ceramics and two types of cementitious materials of both concrete and mortar were used as face materials with various thickness in this experiments. As a result, the predictive equation is clarified to be effective in case of ceramics and ready carbonated cementitious materials by an amendment to the original one called "time equivalent law" as well as in case of cementitious face materials.
\end{abstract}

Keywords: ceramics masonry units, carbonation, grout, physical life time,

effective thickness, carbonation resistance

セラミックメーソンリーユニット、中性化、グラウト、物理的寿命、

有効厚さ、中性化抵抗

1. はじめに

鉄筋コンクリートの物理的な寿命は、基本的にコンクリートの中 性化が鉄筋位置まで到達するのに要する時間とする〔1〕のが最も 普及した考え方（以下、このような考え方を中性化寿命説と呼 ぶ。）であり、この時間はコンクリートの材質・表面材等の各種の 要因に影響される。ここでは、コンクリートのようなセメント系材 料をグラウトした焼成セラミックス系の型伜状ユニット〔5〕を用 いるメーソンリー構造の物理的な寿命を中性化寿命説に基づいて予 測する方法に関して略算的な手法を提案し、その有効性を焼成セラ ミックス系の表面材の材質・厚さ、さらに内部のコンクリートの材 質を変化させた包括的な実験により検討した結果について報告す る。その結果、表面材の材質がそれ自体は中性化する能力がなく、 打込み型枠材のようにコンクリートの表面材として一体的に成形し た注1 ときにおける、竣工時から開始するグラウトとしての内部の コンクリートの中性化の進行状態を予測できるようになる。その成 果は、型枠状の焼成セラミックユニットを用いる補強メーソンリー 構造の物理的寿命だけでなく、焼成セラミックスを表面材とする鉄 筋コンクリート構造の物理的寿命を大きくするための手法が明確に なると考える。また、ここで得られた知見は、以上の他棟瓦仕上げ の躯体へのアンカー部に対するかぶり厚さの所要値を求めるために も活用できる。

\section{Notations}

Ac : carbonation coefficient of inner concrete

$A_{f}$ : carbonation coefficient of outer concrete as face materials

$\mathrm{A}_{\mathbf{f}}{ }^{*} \quad$ : imaginary carbonation coefficient of outer ceramics as face materials

$D_{f o}:$ thickness of outer concrete and ceramics

$D_{e} \quad$ : effective thickness of outer concrete for evaluating carbonation

$\mathrm{T}$ : exposure time

D : carbonation depth

$D_{c}$ : thickness of cover

$\mathrm{T}_{1}$ : exposure time at completely carbonating outer concrete

$\mathrm{T}_{2}$ : exposure time at completely carbonating inner concrete with the same thickness of outer concrete

$\mathrm{L}_{\mathrm{a}}$ : life time of composite concrete with outer concrete and inner one

$\mathrm{L}_{\mathrm{ao}} \quad$ : life time of inner concrete without any outer concrete

$\mathrm{R}$ : carbonation resistance of outer concrete as face materials
$*$ 建設省 建築研究所 先端技術研究官・工博

**通商産業省 工業技術院 九州工業技術研究所 主任研究官・博士 (工学)
Research Director for Advanced Technology, Building Research Institute, MOC, Dr. Eng.

Senior Research Scientist, Kyushu National Industrial Research Institute, Agency of Industrial Science and Technology, MITI, Dr. Eng. 


\section{2. 㽪往の研究}

打込み型染構法や型染状メーソンリー構法のように無機枋料をコ ンクリートの表面材として一体化させた複合コンクリートの中性化 に関しては、振動加圧成形方法によって製造したコンクリートを表 面材とする複合コンクリートの中性化に関する促進実験の結果

(3)について報告されている程度である。この研究における表面 材としてはコンクリートが使用されており、ここで研究の対象とし ている阽土を焼成した搷瓦のようなセラミックス系材料を表面材と する複合コンクリートの中性化に関する系統的な研究は著者らの知 る限り全くない。

ここで、この表層および内部の 2 種類のコンクリートから構成さ れる複合コンクリートにおける内部のコンクリートの中性化進行 は、いわゆる「等価時間の法則」によって説明することができる

〔3〕。すなわち、内部のコンクリートはそれが単体で暴露される ときの中性化深さと暴露時間（以下、単に時間と呼ぶ。）との関係 〔1〕の途中のある時間以降の関係となり、その時間は表層のコン クリートの厚さのすべてが中性化する時間、すなわち「等価時間」 となることが示されている〔3】。

燌瓦仕上げの躯体へのアンカー部に対するかぶり厚さについて は、現行の日本建築学会建築工事標準仕様書メーソンリー工事（ JASS 7)においても明確に規定されておらず、実際の䐈瓦穞張り構 法・䐈瓦パネル打込み型㭝構法における経験的な值があるのみであ る(3)。

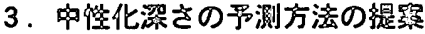

3. 1 等価時間の法則の適用

ここでは、「等価時間の法則」〔3〕は、空気中から侵入してく る炭酸ガスと反応する水酸化カルシウムのようなアルカリ性の物質 を含まない、すなわち、中性化する能力のない焼成セラミックス等 の無機枋料を表面枋とする複合コンクリートの中性化進行に対して も桩大して適用できる方法に関して一提案を行う。

\section{3．２２相複合コンクリートの中性化㵖さの予測}

外部に面する表層材のコンクリートの中性化潹さ、ならびに表面 材のコンクリートの中性化後における内部のコンクリートの中性化 深さは、以下のように表現できる〔3]。

i）中性化深さ $\mathrm{D} か ゙$ 表層のコンクリートの厚さ $\mathrm{D}_{\mathrm{fo}}$ より小さいと き、すなわち $\mathrm{D} \leqq \mathrm{D}_{\mathrm{fo}} 、 \mathrm{~T} \leqq \mathrm{~T}_{1}=\mathrm{D}_{\mathrm{fo}}{ }^{2} / \mathrm{A}_{\mathrm{f}}^{2}$ のとき、

$$
\mathrm{D}=\mathrm{Af} \sqrt{\mathrm{T}}
$$

ii） 中性化深さ $\mathrm{D} か ゙$ 表面材としてのコンクリートの厚さ $\mathrm{D}_{\mathrm{fo}}$ より大 きいとき、すなわち $\mathrm{D} \geqq \mathrm{D}_{\mathrm{fo}} 、 \mathrm{~T} \geqq \mathrm{~T}_{1}=\mathrm{D}_{\mathrm{fo}}{ }^{2} / \mathrm{A}_{\mathrm{f}}{ }^{2}$ のとき、

$$
\mathrm{D}=\mathrm{Ac}(\sqrt{\mathrm{T}}-\mathrm{R})+\mathrm{D}_{\mathrm{fo}}
$$

以上の式を表面および内部のコンクリート単体をそれぞれ中性 化させたときの中性化深さと時間との関係とともにFigure 1に示 す。同図は表面材としてのコンクリートの中性化速度係数 $\mathrm{A}_{\mathrm{f}}$ が内部 のコンクリートのそれ $\mathrm{A}_{\mathrm{c}}$ より大きい場合に対応している。かぶり 厚さDcまで中性化が進行したときを寿命とすると、内部のコンク リート単体のときの寿命は $\mathrm{L}_{\mathrm{a} 0}$ となり、表面から $\mathrm{D}_{\mathrm{fo}}$ までのコンク リートの中性化速度係数が $\mathrm{A}_{\mathrm{f}}(\mathrm{Af} \geqq \mathrm{Ac})$ と低下したときの複合コ

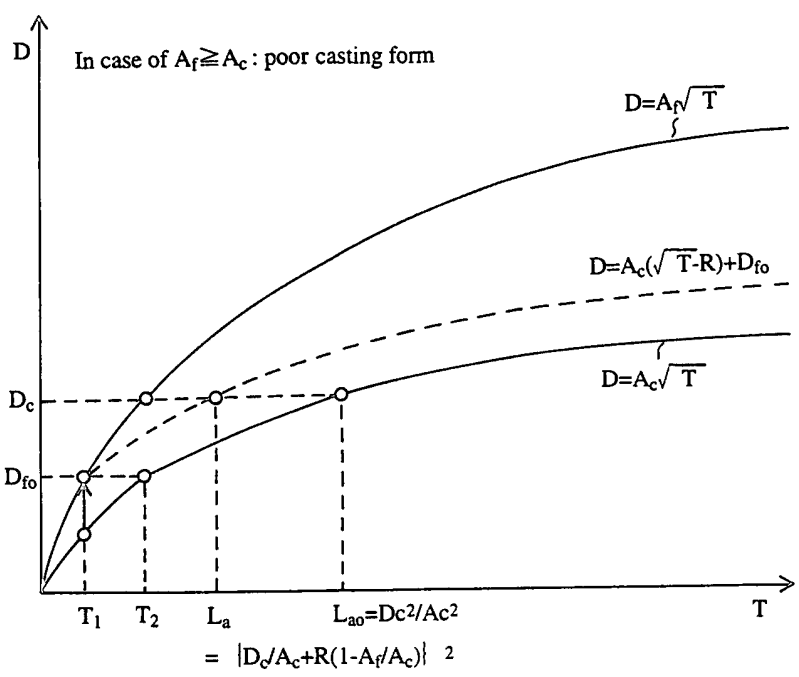

Figure 1 Schematic diagram on predictive relationships between carbonation depth and exposured time of two phase concrete in case of lowly qualified face materials

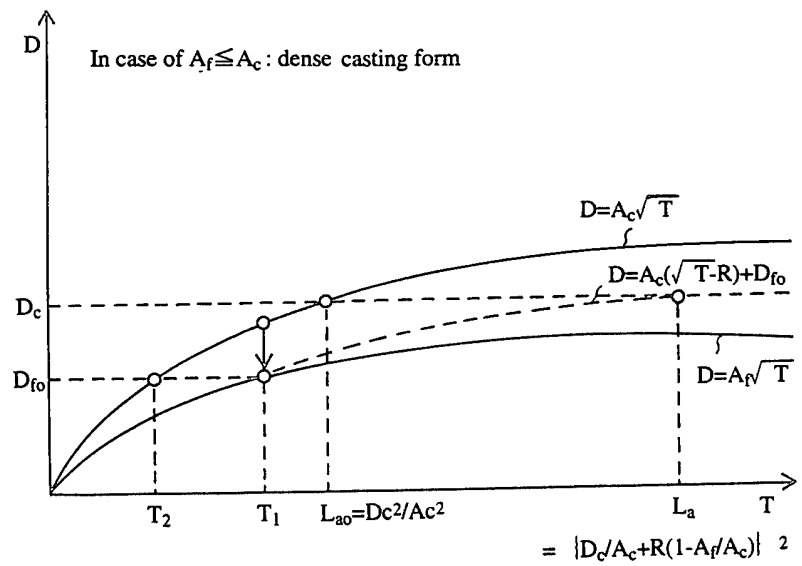

Figure 2 Schematic diagram on predictive relationships between carbonation depth and exposured time of two phase concrete in case of highly qualified face materials

ンクリートの寿命 $\mathrm{L}_{\mathrm{a}}$ は、 $\mathrm{L}_{\mathrm{a} o}$ より小さくなる。これは、中性化速度 係数の大きい打込み型梊材を用いた場合はもちろん、コンクリート 単体が荃生不足によって表面付近のコンクリートの品質の低下に伴 う中性化速度係数の変化に相当すると考えられる。

一方、 $\mathrm{A}_{\mathrm{f}} \leqq \mathrm{A}_{\mathrm{c}}$ の場合についてFigure 2 に示す。同図においては、 高品質の打込み型扏材を表面のコンクリートとした場合の中性化の 進行状態を表している。これは長寿命化した鉄筋コンクリートに相 当すると考えられる。ここで、表面材としてのコンクリートの材質 および形状をそれぞれ代表する尺度 $\mathrm{A}_{\mathrm{f}}$ および厚さ $\mathrm{D}_{\mathrm{fo}}$ を自由に選択 するときに、中性化寿命説に基づく複合コンクリートの寿命は(3)式 で表現できる。

$$
\mathrm{L}_{\mathrm{a}}=\left\{\mathrm{D}_{\mathrm{c}} / \mathrm{A}_{\mathrm{c}}+\mathrm{R}\left(1-\mathrm{A}_{\mathrm{f}} / \mathrm{A}_{\mathrm{c}}\right)\right\} 2
$$

以上をFigure 3 にまとめると、(2)式は、最も一般的な表面枋とし ての中性化していないコンクリートを構造材として用いる場合、す なわち敢て述べれば原点が 0 のときの関係である。一方、表面のコ ンクリートを躯体の一部之考えない、すなわち仕上げ材と考えた場 合は、原点を $0 か ら 0_{1} に D$ 軸方向に $\mathrm{D}_{\mathrm{fo}}$ だけ移動すると(4)式が得られ る。 


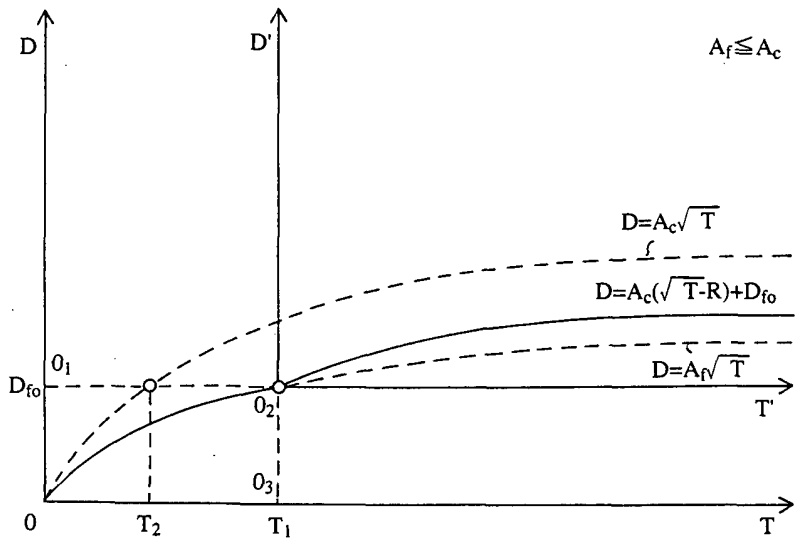

Figure 3 Schematic diagram on predictive relationships between carbonation depth and exposured time of two phase concrete for explaining in case of various combinations of alkalinity and structural face with high quality

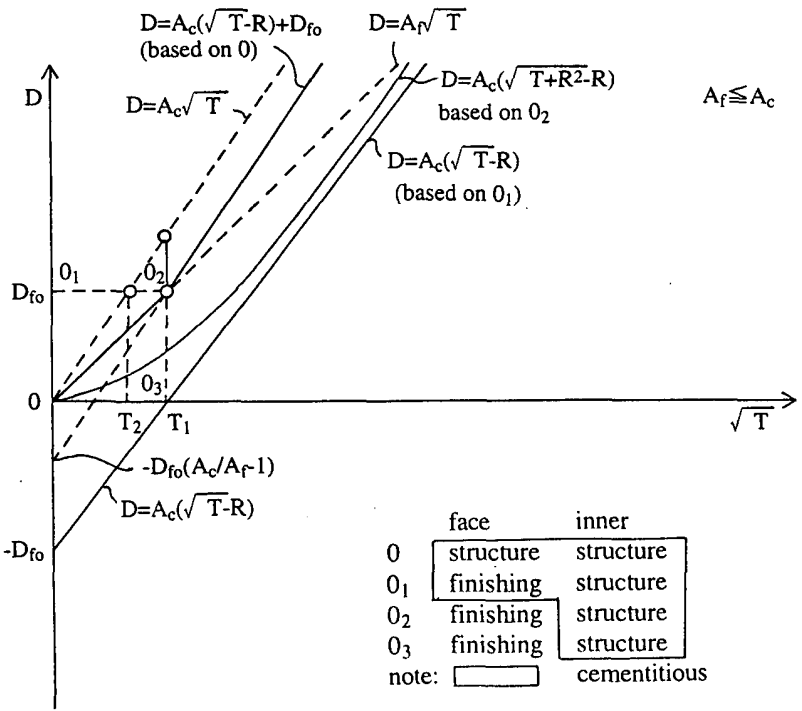

Figure 4 Schematic diagram on predictive relationships between carbonation depth and square root exposured time of two phase concrete for explaining in case of various combinations of alkalinity and structural face with high quality

$\mathrm{D}=\mathrm{Ac}(\sqrt{\mathrm{T}}-\mathrm{R})$

$-(4)$

このとき、 $\mathrm{T}$ 軸切片は $\mathrm{T}_{1}\left(\mathrm{R}^{2}=\mathrm{D}_{\mathrm{fo}_{\mathrm{o}}} / \mathrm{A}_{\mathrm{fo}}{ }^{2}\right.$ に等しい。)、 $\mathrm{D}$ 軸切片は $-\mathrm{D}_{\mathrm{fo}}$ となる。

さらに、表面材としてのコンクリートが既に中性化している場合 は、表面材としてのコンクリートを躯体コンクリートとして考えて いないというだけでなく、竣工時にすでに中性化しているというこ とで、原点をさらに $0_{1}$ から $0_{2} に$ 移動し、結果として原点が0から $0_{2}$ に移動することになり、(5)式が得られる。

$$
\mathrm{D}=\mathrm{A}_{\mathrm{c}}\left(\sqrt{\mathrm{T}+\mathrm{R}^{2}}-\mathrm{R}\right)
$$

最後に、既に中性化した表面材を構造体として用い、表面材の外 部表面を中性化測定の原点とすると、座標軸の原点を $\mathrm{O}_{3}$ に移動す ることになり、(6)式が得られる。

$$
\mathrm{D}=\mathrm{A}_{\mathrm{c}}\left(\sqrt{\mathrm{T}+\mathrm{R}^{2}}-\mathrm{R}\right)+\mathrm{D}_{\mathrm{fo}}
$$

3. 3 表面材を焼成セラミックスとする構造体としての複合コ ンクリートの中性化深さの予測

Figure 4は 3 ．２に述べた複合コンクリートの中性化進行につい て成立する「等価時間の法則」を基礎に、表面材の材質および厚さ を変化することによって寿命の延長が期待できる場合、すなわち $\mathrm{A}_{\mathrm{f}}$ $\leqq \mathrm{A}_{\mathrm{c}}$ の場合の中性化深さと時間の平方根との関倸を示している。 ここで、表面材としてのコンクリートを内部のコンクリートと複合 するときに、既に中性化している表面材としてのコンクリートを媒 介とする内部のコンクリートの抑制された中性化の進行状態は、同 図において座標の原点を 0 から $0_{3} に$ 移動したときに相当する。ここ で、この状態を表す式は原点を通り、内部のコンクリートは竣工時 から中性化することとなる。したがって、この式における中性化速 度係数は、中性化する以前の表面材としてのコンクリートと同一の 炭酸ガスの透過性をもうアルカリ性をもたない焼成セラミックスに 関する值であり、複合コンクリートの寿命を表面材を中性化するに 必要な時間だけ短くする点で表面材を未中性化のコンクリートとす る場合と異なり、同じ炭酸ガスの透過性の尺度であるという物理的 な意味でしかない。ゆえに、このような場合の中性化速度係数は、 これまでの中性化速度係数ではなく「仮想の中性化速度（imaginary carbonation coefficient, $\left.\mathrm{A}_{\mathrm{f}}{ }^{*}\right) 」$ と呼ぶこととする。

さらに、以上の考え方を現実にあり得る各種の場合について Figure 4を用いて説明する。先ず、表面材の厚さ $\mathrm{D}_{\mathrm{fo}}$ の一部すら中性 化していない表面材としてのコンクリートを構造体として活用する 場合における中性化の進行状態は、(2)式で表現できる。次に、ここ で表面材を構造体として考えない場合については、(4)式で表現でき る。さらに、アルカリ性を含まない焼成セラミックスの仕上げで は、(5)式で表現できる。最後に、焼成セラミックスを構造体とする 場合は(6)式で表現できることになる。まとめると、以上の 4 つの場 合はFigure 4 において原点が $0 、 0_{1} 、 0_{2}$ および $0_{3}$ の場合に相当する。

焼成セラミックスまたは既に中性化したコンクリートを仕上げと しての表面材とする場合の内部のコンクリートの中性化深さと時間 との関係（(5)式、原点 $0_{2}$ ）は、表面材としてのコンクリートが躯 体である場合（(2)式、原点0）と仕上げである場合（(4)式、原点 $0_{1}$ ）の同関係の中間となることが判る。さらに、焼成セラミック スまたは既に中性化したコンクリートを表面材としてもつコンク リートの中性化深さは、長時間経過後において表面のコンクリート を仕上げとした場合の中性化進行の状態に漸近する。

次に、構造体として焼成セラミックス系表面材を用いる場合（(6) 式、原点 $0_{3}$ ）は、前述の表面材の仕上げとしての関係を $\mathrm{D}_{\mathrm{f} 0}$ だけ上 方に移動させたものとなる。

\section{4. 実験による検証}

\section{1 材料および試験体}

検証のための実験に当っては、表面材の性質・嬮さおよび内部の コンクリートの性質という 3 つの材料・構法要因を変化させて、ど のような材質の表面材をどの程度の厚さとして取り付けると、どの ような材質の内部のコンクリートではどのように中性化が進行する か、実験によって得られるように工夫した。これにより、現実に内 部の鉄筋が腐食し始める時間を遅くする観点からの上述の 3 つの要 
因の影響度を定量的に評価できるようになる。すなわち、耐久性制 御のための枋料・構法設計の基本的な資料が得られる。

したがって、材料選定に関しては、以下の事項に留意した。

1 ）表面のコンクリートを同一の材料・調合下で全断面中性化した ものと、全く中性化していないものとを比較できる。

2 ）圧縮強度の異なる焼成セラミックスを表面材として緻密さの違 いによる中性化抑制効果を比較できる。

3）表面材としてコンクリートのようなセメント系材料と焼成セ ラミックスとを用いた場合の中性化抑制効果を比較できる。

このような観点から、表面材としてはTable 1に示す枋料を選定し た。試験体は、Figure 5に示すように、75mmx75mmx300 $\mathrm{mm}$ の 直方体とし、その直方体を形成する型染の両側表面部にTable 1 に 示した材料を設置し、その間にコンクリートを充填して作製した。 ここで、表面材の厚さは $7 \mathrm{~mm}$ から $23 \mathrm{~mm}$ までの7水準としたものを 作成した。また、内部のコンクリートを充填したときの表面材は、 表面乾燥内部飽水状態とした。所定の盖生後、コンクリートが外気 に接することがないように、ガラス繊維混入のエポキシ樹脂で残り の 4 面をシールした。

内部のコンクリートは圧縮強度レベルで 3 種類とし、その材料お よび調合をTable 2に示す。ここで、表面材である焼成セラミックス の圧縮強度測定用の試験体は、 $50 \mathrm{mmx} 50 \mathrm{mmx} 50 \mathrm{~mm}$ の立方体と し、加力面を平行・平坦・平滑になるように研磨し、24時間水中

Table 1 Kinds and properties of face materials

\begin{tabular}{lllll}
\hline $\begin{array}{l}\text { Sign } * 3 \text { of } \\
\text { materials }\end{array}$ & $\begin{array}{l}\text { Kinds of } \\
\text { materials }\end{array}$ & $\begin{array}{c}\text { Surface dry } \\
\text { density }(\mathrm{g} / \mathrm{cm} 3)\end{array}$ & $\begin{array}{l}\text { Compressive } \\
\text { strength(MPa) }\end{array}$ & $\begin{array}{l}\text { Water absorption } \\
\text { rate(\%vol) }\end{array}$ \\
\hline CL1 & burnt clay & 2.265 & 109.8 & 10.4 \\
CL2 & burnt clay & 2.380 & 72.9 & 7.1 \\
CL3 & burnt clay & 2.353 & 61.8 & 7.2 \\
CL4 & burnt clay & 2.266 & 38.0 & 17.4 \\
UN1(CN1) & concrete*1 & 2.186 & 18.2 & $\ldots$ \\
UM1(CM1) & mortar*2 & 2.089 & 20.0 &.-- \\
\hline
\end{tabular}

(Note) $* 1$ Produced by vibrio-pressing methods.

* 2 Produced by cast moulding methods.

*3 UN and UM mean uncarbonated concrete and mortar. And CN and CM also mean carbonated ones.

Table 2 Mix proportions and properties of concrete grouted in specimens

\begin{tabular}{llllll}
$\begin{array}{l}\text { Sign of } \\
\text { concrete }\end{array}$ & Mix proportions & $\begin{array}{l}\text { W/C } \\
(\% \text { Ut) }\end{array}$ & $\begin{array}{c}\text { Unit cement } \\
\text { content }\left(\mathrm{kg} / \mathrm{m}^{3}\right)\end{array}$ & $\begin{array}{l}\text { Compressive } \\
\text { strength(MPa) }\end{array}$ \\
\hline 25 & $1: 3: 2$ & 65.0 & 354 & 29.0 \\
35 & $1: 2.4: 1.6$ & 56.0 & 422 & 37.1 \\
45 & $1: 2: 1.33$ & 44.4 & 497 & 51.4 \\
\hline
\end{tabular}

Table 3 Specimens as combinations between face materials and inner concrete

\begin{tabular}{lllllllll}
\hline $\begin{array}{l}\text { Face } \\
\text { materials }\end{array}$ & CL1 & CL2 & CL3 & CL4 & UN1 & CN1 & UM1 & CM1 \\
\cline { 1 - 4 } Inner concrete & & & & & & & & \\
\hline 25 & $\bigcirc$ & $\bigcirc$ & $\bigcirc$ & $\bigcirc$ & $\bigcirc$ & $\bigcirc$ & $\bigcirc$ & $\bigcirc$ \\
35 & $\bigcirc$ & $\bigcirc$ & $\bigcirc$ & $\bigcirc$ & $\bigcirc$ & $\bigcirc$ & $\bigcirc$ & $\bigcirc$ \\
45 & $\bigcirc$ & $\bigcirc$ & $\bigcirc$ & $\bigcirc$ & $\bigcirc$ & $\bigcirc$ & $\bigcirc$ & $\bigcirc$ \\
\hline
\end{tabular}

(Note) Thickness of all the face materials is $7,9.6,12.3,15,17.6,20.3,23 \mathrm{~mm}$ respectively.
浸漬したものとした。したがって、表面のコンクリートおよび内部 のコンクリートの強度も同じ寸法として湿空養生28日時において 求めた。また、Table 3に試験体すなわち表面材と内部のコンクリー トとの組合せを示す。

\section{2 促進中性化実験}

試験体の製作後材令28日まで湿空養生し、その後材令56日まで $20^{\circ} \mathrm{C} 、 60 \% \mathrm{RH}$ 室内に放置した。促進中性化実験は、20 $0^{\circ} \mathrm{C} 、 45$ $\% \mathrm{RH} 、 \mathrm{CO}_{2}$ 濃度 $4 \%$ の内部空気擋拌機能のある密封箱により実施 した。また、中性化深さの測定は、試験体の端部から概ね $30 \mathrm{~mm} の$ 所を割裂破断後 $1 \%$ \%エノールフタレインエチルアルコール溶液を ふり掛けて行った。時間は暴露開始から14日、28日、56日および 112日とした。測定は切出した小片部で行い、試験体は端部をアス ファルトとアルミニウムとでシールし、次の所要の時間におけるま でシールした端部から $\mathrm{CO}_{2}$ ガスが侵入しないようにした。中性化深 さは、Figure 5 に示すようにシールしていない側面部を高さ方向に 8 等分にし、中間の 7 つの分割位置における測定值の平均値を中性 化梁さとした。

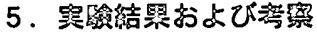

5. 1 中性化深さと時間との関係

主として表面材および内部のコンクリートの材質の効果について

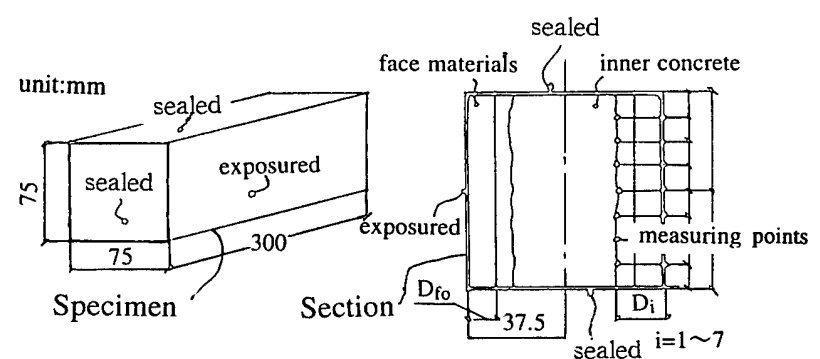

Figure 5 Specimens for accelerated carbonation tests of two phase concrete with ceramic face materials

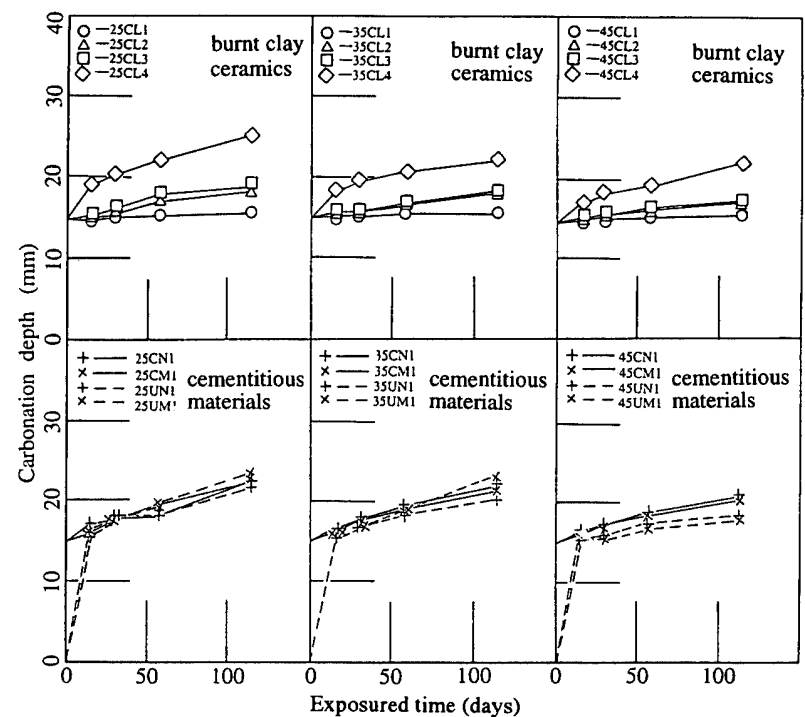

Figure 6 Experimental relationships between carbonation depth and exposured time of two phase concrete in case of standard thickness of ceramic face materials 
考察するために、中性化深さと時間との関係を表面材が $15 \mathrm{~mm}$ の場 合を例としてFigure 6に示す。ここで、縦軸に示す中性化深さは表 面材の外表面を原点として表現した。同図上部に示す燒成セラミッ クスを表面材とする場合について以下の傾向が観察される。

1）暴露開始と同時に内部のコンクリートの中性化が開始する。

2) 中性化速度は初期において急速,後期において緩慢である。

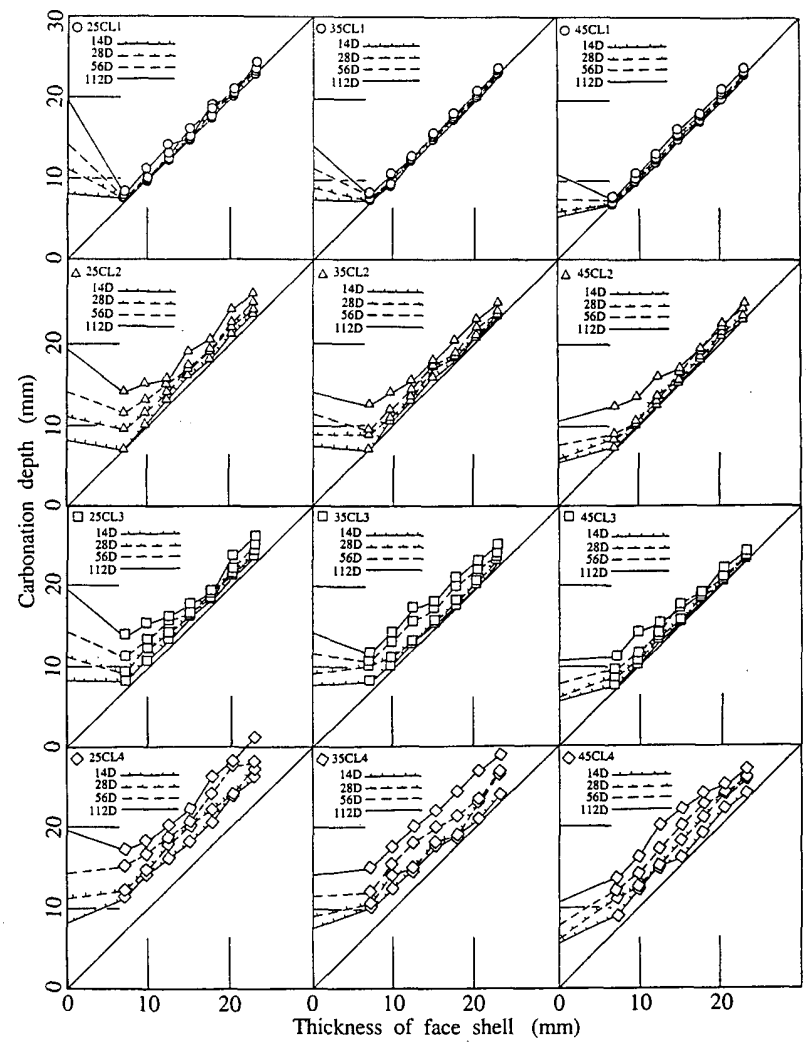

Figure 7 Experimental relationships between carbonation depth and thickness of ceramics face materials of two phase concrete in case of varied thickness of ceramic face materials

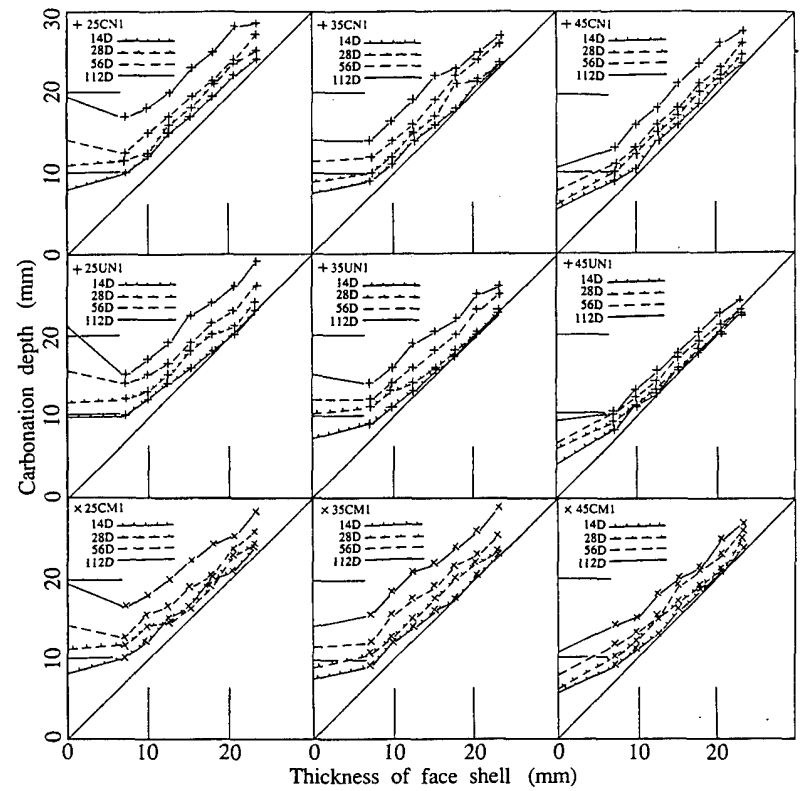

Figure 8 Experimental relationships between carbonation depth and thickness of ready or non carbonated face materials of two phase concrete in case of varied thickness of cementitious face materials
3 ）表面材の圧縮強度が大きくなるほど、内部のコンクリートの中 性化速度は小さい。

4) 内部のコンクリートの強度が大きいほど、中性化は小さい。

5) CL1のような高強度の焼成セラミックスという表面材と高強度 のセメント系材料とを組合せによって、かぶり厚さを確保しに くい部位における中性化に伴う耐久性の欠如を防止できる。

また、同図下部にそれぞれ 1 種類のコンクリートとモルタルとを 全厚さを中性化したもの（CN1およびCM1）と全く中性化してい ないもの（UN1およびUM1）とを表面材とした場合の実験結果を 示す。この結果からセメント系および非セメント系表面材との中性 化の進行状態の比較において以下の傾向が観察される。

1）コンクリートおよびモルタルとを既に中性化させた表面材の場 合は、焼成セラミックスの場合と同様に暴露開始時点から内部 のコンクリートの中性化が開始する。

2) ここで用いた一般的な強度のコンクリートおよびモルタルにお ける非中性化の表面材と既中性化のそれとの中性化の進行状態 は、極く初期を除いて同程度である。

3）コンクリートおよびモルタルとを既に中性化させた表面材の場 合でも、同一強度の焼成セラミックスの表面材と比較して中性 化抑制効果が大きい。

4）内部のコンクリートの強度が大きいほど、中性化の進行が遅い。

\section{2 中性化深さと表層材の厚さとの関係}

Figure 7では構造体としての焼成セラミックスの表面材の材質お よび厚さが各種の強度のコンクリートの中性化に対する効果につい て、包括的な知見を得るために、焼成セラミックス系の表面材の厚 さと内部のコンクリートの中性化深さとの関係を時間をパラメー ターとして表現した 12 種類の結果を、表面材および内部のコンク リートの材質を主要な指標である圧縮強度別に上部ほど表面材の強 度が大きく、右側ほど内部のコンクリートの強度が大きくなるよう に配列した。ここでも、中性化深さはFigure 6と同様に表面材の外 表面を原点として(6)式に対応するように表現した。したがって、全 ての実験結果は同図における 45 度の斜線より上部に存在する。ま た、内部のコンクリート単味の中性化深さの実験結果を縱軸の切片 に示す。同図に示す実験結果から中性化の進行状態に表面材の厚さ の及ぼす影響について、以下の傾向が観察される。

1 ）中性化深さは表面材の厚さが小さいほど小さくなり、厚さが 10mm以下において極小值が存在することがある。

2 ）極小值は、表面材の強度が大きいほど、内部のコンクリートの 強度が小さいほど、時間が経過するほど確実に存在する。

3 ）表面材裏面（斜線）を原点とする中性化深さは、表面材の強度 が大きくなるほど、厚さが大きくなるほど、小さくなる。

また、Figure 8にはFigure 6の下部に示した構造材としてのコンク リートおよびモルタルの既中性化表面材と未中性化表面材とに関し て、内部のコンクリートの中性化深さと表面材の厚さとの関係を示 す。このセメント系および非セメント系表面材に関する実験結果に おいても、焼成セラミックスの表面材についての前述の 3 つの傾向 が成立する他以下の傾向が観察される。

1）極小值が明確に現れるのは内部のコンクリートの強度が小さい （25MPa）時に限られた。 
2 ）未中性化の表面材の場合は、同質の既中性化の表面材の場合と 比較して極小値を得られやすい。

以上の表面材の材質および厚さに関する実験結果より、セメント 系でない表面枋を用いる場合においても、中性化寿命説に基づいて 長寿命化するための条件が明確になるとともに、中性化深さが極小 値を含めて最小となる表面材の材質・厚さおよび内部コンクリート の条件を求めることができる。

\section{3 中性化深さの予測方法}

既に中性化した表面材および中性化することのない焼成セラミッ クス系の表面材を媒介とする表面材の裏面を原点とする内部のコン クリートの中性化潹さと時間との関係について、5，1および $2 に$ 示した実験值に対する 3.3 で述べた予測式の適合性を検討した結 果についてFigure 9に示す。同図に示すように「等価時間の法則」 による関係において座標軸の原点を等価時間分だけ移動した時に求 められるFigure 3 において $0_{2}$ を原点とする関係(5)式によって予測で きる。Figure 9 においては、縦軸をコンクリートの中性化速度係数 当りの中性化滋さとして、横軸を時間と中性化抵抗の自乗との和の 平方根から同抵抗値を引いた值として表現している。この時、45 度の斜線上に実験值が集っているので、3. 中性化滋さの予測方法 が表面材の材質・厚さおよび内部コンクリートの材質を変化させた とき有効であることを表している。ただし、ここでは圧縮強度 38MPaから110MPaの雑跕土を原料とする焼成セラミックスを厚さ 7 から $23 \mathrm{~mm}$ の厚さとし、圧縮強度30MPaから50MPaのコンク リートの表面に取り付けた場合に限られている。また、3，2の(5) 式における中性化抵抗は、4つの時間における中性化深さの 7 つの 測定値の平均値から逆算した値とした。

\section{4 中性化速度係数}

既に中性化した表面枋および中性化することのないセラミックス の表面材の中性化抑制効果に関しては、(5)式が成立するので、「仮 想の中性化速度係数（imaginary carbonation coefficient, $\mathrm{A}_{\mathrm{f}}{ }^{*}$ )」と表面 材の圧縮強度との関係を求めると、Figure10のようになる。このよ

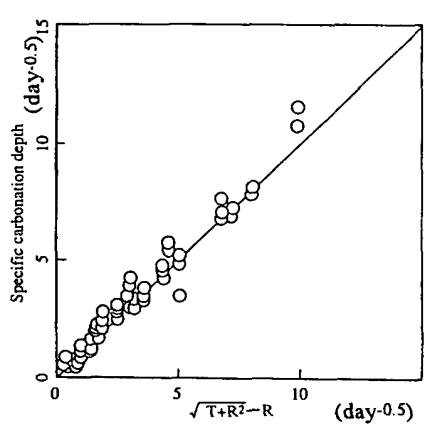

Figure 9 Experimental examinations on predictive relationships between carbonation depth and exposured time of two phase concrete with varied thickness of ceramic face materials

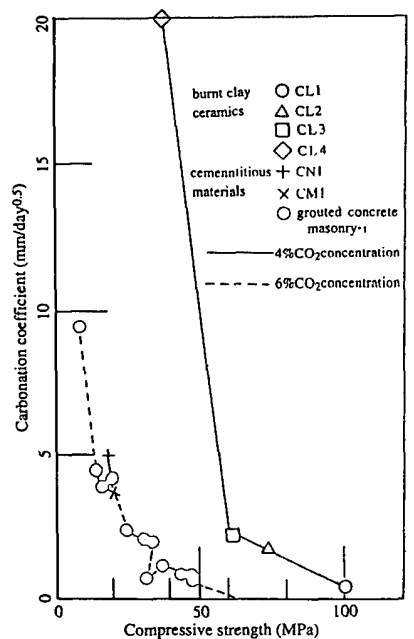

Figure 10 Relationship between imaginary carbonation coefficient and compressive strength of ceramic face materials
うに、同係数は圧縮強度が大きいほど小さくなった。同図におい て、本論文での焼成セラミックス系の表面材に関する仮想の中性化 速度係数の他に、既往のセメント系表面材に関する実験結果〔3] による中性化速度係数についても比較のために示す。ここで、セメ ント系の実験結果の多くがCO $\mathrm{CO}_{2}$ 濃度 $6 \%$ で、この論文に示したセメ ント系と焼成セラミックス系の場合が $4 \%$ であるが、前者と後者の セメント系との実験結果が大きく異ならないこと、さらに既往の $\mathrm{CO}_{2}$ 濃度の影響に関する研究〔6〕より両者の中性化速度係数の比 は湄度の比の平方根程度であることを考慮すると、同一圧縮強度に 対する同係数は焼成セラミックス系の方がセメント系より大きい傾 向であると言える。別の表現を㨙用すれば、セメント系では圧縮強 度で $60 \mathrm{MPa}$ 程度以上とすることによって内部に接するセメント系 材料の中性化の進行を防止できる〔3〕が、焼成セラミックス系に おいて同様の効果を得るためには100MPa必要であることが判か る。ここで、仮想の中性化速度係数の個々の值は、5．3で述べた ように測定位置および暴露材齢の異なる合計 28 の值の平均值であ る。

\section{6. 缩籍}

以上に述べた実験結果と考察から、焼成セラミックスの表面材を 媒介とした内部のコンクリートの中性化の進行状態に関して、以下 のようなことが結論できる。

1) 内部のコンクリートの中性化の進行は、表面材の圧縮強度が大 きいほど、内部のコンクリートのそれが大きいほど、遅い。

2) セメント系の表面材の場合と同様に、焼成セラミック系の表面 材の場合における内部のコンクリートの中性化は、「等価時間 の法則」によって求められる中性化深さと時間との関係を時間 軸方向に等価時間だけ平行移動することによって求められる。

3）表面材の外表面を基準とした中性化深さを最小値とする表面材 の厚さが存在し、その值は表面材の強度が大きいほど、内部の コンクリートの強度が小さいほど、さらに時間が経過するほ ぞ、際立つ。

4）表面材の中性化抑制効果を表わす「仮想の中性化速度係数」 は、その圧縮強度が大きいほど小さいが、同強度のセメント系 材料より小さい。

5 ）焼成セラミックスを媒介とする中性化は、同材料の圧縮強度が 100MPa以上になると概ね進行しなくなる。

参考文献

〔1〕岸谷孝一、鉄筋コンクリートの耐久性、鹿島出版会、 1963年

〔2〕日本建築学会、建築工事標準仕様書メーソンリー工事 JASS7、1992年

〔3〕馬場明生、千歩修、松島泰幸、羽木宏、グラウトしたコンク リートメーソンリーの中性化、日本建築学会構造系論文集、 1997年 8 月

(4) A. Baba and F. D. Beresford, "Carbonation of Reinforced Masonry, "7th International Brick Masonry Conference, Melbourne, Australia, Feb., 1985

〔5〕日本工業規格、建築用セラミックメーソンリーユニット、 JIS A 5406、1994年

〔6〕阿部道彦他、コンクリートの促進中性化試験法の䛨価に関 する研究、日本建築学会構造系論文報告集、1990年 3 月 